\title{
Project Management Methods in Projects Co-financed by EU Funds
}

\author{
Jana Kostalova, Libena Tetrevova, Michal Patak
}

\author{
University of Pardubice \\ Studentska 95, Pardubice, Czech Republic \\ E-mail.jana.kostalova@upce.cz,libena.tetrevova@upce.cz,michal.patak@upce.cz
}

cross $^{\text {ref }} \underline{\text { http://dx.doi.org/10.5755/j01.ee.28.3.13651 }}$

\begin{abstract}
This paper deals with the management of projects co-financed by European Union funds (structural funds and the Cohesion Fund) in the Czech Republic (EU projects). The authors aimed to analyze and assess the scope of familiarity with basic project management methods and their application within the implementation of EU projects in the Czech Republic in the Programming Period 2007-2013. Based on a questionnaire survey of EU project organisers, the authors evaluate their attitudes to project management methods as effectiveness improvement tools. The analysis also considers the degree of dependence between familiarity with project management methods, their application, and their effectiveness as perceived by EU project organisers. Finally, it presents recommendations to the institutional authorities and project organisers with respect to applications during the Programming Period 2014-2020. We can state that project management methods were not applied to a sufficient extent. To improve the effectiveness of the implementation of EU projects, EU fund provider's methodical instructions have to include the obligations or recommendations to apply project management methods, mainly methods applicable within more project management knowledge areas and within more project life cycle stages (i.e. Logical Framework, Pre-Project Study with Formalized Structure, Formalized Risk Analysis and Formalized Project Communication Plan).
\end{abstract}

Keywords: Project, Project Management, Project Management Methods, European Union Funds, Projects Co-Financed by the European Union Funds.

\section{Introduction}

For the Programming Period (PP) 2007-2013, 70,651 projects co-financed by EU funds (EU projects) were approved in the Czech Republic (CZ) as of 31 December 2015 (Ministry of Regional Development CZ, 2016). It is now desirable to assess the way in which these projects were implemented. In view of the start and running of PP 2014 2020, it is necessary to make a detailed analysis of the setup of the support provision system (Krisciunaite-Kaciuskiene, 2013; Kostalova et al., 2015) and, project organisers' implementation procedures in order to be able to achieve even better results in the subsequent PP. This paper focuses on the latter area, i.e. on an assessment of implemented projects from the point of view of the application of project management (PM) methods. This assessment is important and necessary with respect to a significant volume of the financial means reallocated in this respect on both the national and European levels. It may also contribute to a more effective way of utilizing public resources.

The scope of the application of PM methods in EU projects is influenced by two basic factors. First of all, it depends on the scope of familiarity with these methods and the experience of project organisers with their application. Generally, the preparation of applications and project implementation are influenced by the level of familiarity with PM (Grant \& Pennypacker, 2006). Also, it is important how these methods are defined and required within the instructions of the financial support providers.

PM plays an irreplaceable role within the implementation of any type of project, i.e. also EU projects. According to the Project Management Institute
(2004), "PM is the application of knowledge, skills, tools and techniques to project activities to meet project requirements. It is accomplished through the application and integration of the PM processes of initiating, planning, executing, monitoring and controlling, and closing." PM is applied using suitable methods which are specified in the PM standards of the three biggest branch organizations: the Project Management Institute (PMI), the International Project Management Association (IPMA), and PRojects IN Controlled Environments 2 (PRINCE 2). A significant effect of the application of PM methods on increasing the success of project implementation has been demonstrated by a number of studies, e.g. Patanakul et al. (2010), Lappe \& Spang (2014), de Carvalho et al. (2015) and Joslin \& Muller (2015).

\section{Research Objectives}

The presented research aimed:

1) to analyze and assess the scope of familiarity with PM methods among EU project organisers and the degree of their application in PP 2007 - 2013 in the Czech Republic;

2) to analyze the dependence between the scope of familiarity with PM methods among EU project organisers and the effectiveness of PM as perceived by them;

3) to analyze the dependence between the degree of application of PM methods by EU project organisers and the effectiveness of PM as perceived by them;

4) to recommend, on the basis of the outputs of the above objectives, PM methods that contribute most to increased effectiveness of the utilization of public resources. 
To be able to meet the above objectives, it was necessary to address project organisers and ask them to express their attitudes to PM as an effectiveness improvement tool and to identify which PM methods they knew and actively used within project implementation. The outcomes of this survey were subsequently compared with current knowledge and the degree of application of basic PM methods in general practice in the Czech Republic (Ernst \& Young, 2012 and 2013; Kratky et al., 2012). In this way, it was possible to identify the degree to which basic PM methods are known and applied by EU project organisers, also in comparison with general practice.

\section{Literature Review and Research Hypothesis}

\section{Theoretical Framework}

In essence, EU projects do not significantly differ from any other types of projects. Therefore, it is possible to approach their planning and implementation using the basic recommendations, methods, and tools offered by the theory and practice of PM in all knowledge areas (Association of Project Management, 2006; Project Management Institute, 2004; Pitas et. al., 2010; International Organization for Standardization, 2012). There are a wide range of projects, usually medium-term or long-term ones of an investment and operational nature (Tetrevova, 2006), which bring tangible and intangible outputs (Project Management Institute, 2004). These projects are implemented across all branches of the economy, i.e. in the private, public, and nonprofit sectors. Most of them are implemented on the national level, but, thanks to cross-border operational programmes, they can be of an international character (Gareis, 2005). Just as in other types of projects, EU projects are also implemented step by step in stages of the project life cycle (Association of Project Management, 2006; Project Management Institute, 2004; Pitas et. al., 2010; International Organization for Standardization, 2012). Within single project life cycle stages, it is possible to apply PM methods from the respective knowledge areas (project integration, project scope, project time, project cost, project quality, project human resources, project communications, project risk and project procurement management) (Project Management Institute, 2004). However, EU projects have their own specifics, given by the rules set by the provider of the respective financial source (Mihaila, et al., 2014; Gerbault, 2012).

The level of application of PM by EU project organisers can be deduced from how much PM is, within beneficiary organizations, included in common process change management tools in the form of a single PM methodology, and whether activities of a project character are concentrated under a separate organizational unit specializing in PM in the form of a project management office (PMO). The scope of individual PM methodologies may differ. In its basic form it includes the creation of basic templates for the identification of projects and basic processes that have to be observed during project preparation, implementation and evaluation. The broadest form of a single methodology offers complex procedures for the management of various types of projects, a database of potential risks, complete instructions for documenting projects, and usually also software tools for these activities. (Hrazdilova Bockova, 2009; Kerzner, 2005) At the same time, a high level of PM standardization is one of the key factors of project success (Milosevic \& Patanakul, 2005).

A PMO represents an organizational unit with differing scopes of responsibility according to the level of centralization or independence of projects falling within their competence (Project Management Institute, 2004). The scope of their activity may include the provision of basic project support only, or it may also include direct PM. This unit may have various functions within an organization from serving, through controlling, to partnering (Muller et al., 2013; Mariusz, 2014; Hofman, 2014 and Spalek, 2013).

A single methodology and PMO are tools making it possible to apply PM in practice and thus to apply PM methods across the beneficiary organization. PM theory offers a wide range of methods. While some of them are only used in some phases of the project life cycle, others are used over the entire course of project implementation.

To specify project objectives, it is suitable to use the Logical Framework method. The Norwegian Agency for Development Cooperation (1999) defines the Logical Framework as a way of structuring the main project elements, which helps to clarify the purpose and rationale of the project, identify information requirements, define key project elements clearly, and analyze initial project settings. It also supports communication among all involved parties and identifies how the success or potential failure of the project will be measured and evaluated.

One of the methods used for defining a project is the Pre-Project Study with Formalized Structure (Opportunity and Feasibility Study), which serves to assess in detail whether the intention of the project is viable and in compliance with the project organiser's overall strategy. This study should serve as the basis for the primary evaluation of the project from various points of view, and the basis for the decision whether to implement the project under the defined conditions or not (Hapanova \& Al-Jiburi, 2009).

An important area, which is a significant component of $\mathrm{PM}$, is the financial management of projects. Project financial management offers a large number of methods. For the financial evaluation of a project, it is possible to make use of a static method (disregarding the time value of money), e.g. the Payback Period and various dynamic methods (i.e. methods respecting the time value of money), e.g. the Internal Rate of Return (IRR) and the Net Present Value (NPV) (Tetrevova, 2006; Zizlavsky, 2014). It is also possible to apply methods taking account of, for example, the social benefits of projects, e.g. according to Cost Benefit Analysis (Cambell \& Brown, 2003) or the Social Return on Investment (Kratky \& Tetrevova, 2012).

A PM method used in the phase of detailed project planning is the Work Breakdown Structure (WBS). WBS expresses the material dimension of the project and structures the project objective into partial outputs, or deliverables, i.e. unique outcomes that are necessary for implementation of the project objective. These partial outputs are further broken down into so-called work packages, i.e. the lowest necessary component of the project's objective. WBS enables systematic planning and reduces the possibility of omitting key outputs to a minimum. (Norman et al., 2008) 
As for detailed project planning from the point of time, it is possible to use the PM method of Time Planning Using Schedules and the Critical Path Method (CPM), e.g. in the form of Gantt charts. This part of planning includes the definition of all partial activities that are necessary for the implementation of outputs, the time demands of individual activities, and their mutual interconnection and dependence. And all of this also with respect to the availability and performance of individual resources and technological procedures. (Hillier \& Lieberman, 2005)

For the optimization of time plans, it is possible to make use of the Critical Chain Method (Goltratt, 1997). The Critical Chain Method is based on the Theory of Constraints (Dettmer, 1997). Its essence consists in searching for weak points and limitations with respect to the system and planning with the minimum time allocation using time buffers, which makes it possible to adjust the project plan to potential changes during implementation more efficiently.

To monitor progress during project implementation, it is possible to apply the method of Earned Value Management (EVM), which evaluates project advancement. This method compares the planned value of individual activities that are necessary for project implementation with the value achieved at a particular moment. On the basis of this data, it is possible to predict whether the project will be implemented by the planned deadline and the budget kept, or whether the project inclines towards deviations from the plan. (Project Management Institute, 2005; Acebes et al., 2012; Storms, 2008)

For the entire project life cycle, it is necessary to monitor any potential risks (Rodney et al., 2015). Formalized Risk Analysis makes it possible to identify the risks, to assess the probability and potential impacts of the risks, and to take effective measures leading to their elimination over the entire course of project implementation (Benta et al., 2011).

For successful project implementation, it is important to define communication rules. To do so, it is appropriate to use the Formalized Project Communication Plan. It includes the specification of all communication participants within the project and a definition of communication channels. For all types of shared information, it specifies the frequencies and forms in which the information is to be transferred or shared among the participants. (Dow \& Taylor, 2010; Pitas et al., 2010)

Suitable methods for controlling the responsibility for implementing individual activities or outputs within a project are the Responsibility Assignment Matrix or the Linear Responsibility Chart. These methods help assign and display various types of responsibilities to persons responsible for the respective project activity or output. The basic roles that can be assigned to individual persons are: Responsible, Accountable, Consulted, and Informed. (Yang \& Chiu-Wen, 2009; Melnic \& Puiu, 2011)

Recent PM includes so-called Agile Methods. These represent an alternative approach to PM focused more on individuals rather than on process management (Spundak, 2014). It is more open to changes during project implementation and is more oriented on creating outputs in close cooperation with the customer that will receive the project output. It is based on the progressive implementation of outputs and increased flexibility within project advancement, but with a strong emphasis on feedback and the system of checks. (Beck, 2001; Koerner, 2005)

\section{Hypothesis}

The existence of a single methodology, a PMO, familiarity with PM methods, and the application of such methods should be evidence that EU project organisers implement projects in accordance with the principles and procedures of the theory of PM in an effort to ensure the maximum possible effectiveness of their projects.

The instructions and methodologies of EU fund providers on the national level describe PM methods only in very general terms. Also, they are not an obligatory or even recommended part of the terms and conditions of project implementation (with the exception of the Pre-Project Study). This is why it is possible to assume that the level of familiarity with these methods and the degree of their application are lower in this group of project organisers than in general practice in the Czech Republic.

On the basis of the above assumptions, the following hypotheses were proposed:

H1: EU project organisers who have introduced a single PM methodology are more likely to evaluate PM as a tool leading to the improved effectiveness of projects.

H2: EU project organisers who have introduced a PMO are more likely to evaluate PM as a tool leading to the improved effectiveness of projects.

H3: EU project organisers' familiarity with PM methods is on a lower level than it is with project organisers in general.

H4: EU project organisers make use of PM methods to a lesser extent than project organisers in general.

H5: EU project organisers who evaluate PM as a tool for improving the effectiveness of projects have broader familiarity with basic PM methods.

H6: EU project organisers who evaluate PM as a tool for improving the effectiveness of projects are more likely to apply basic PM methods.

\section{Data and Methodology}

The best way to assess how much PM methods are known and applied by EU project organisers, how much a single methodology and a PMO are utilized, and what the organisers' attitudes to the prospective benefits of PM are is to evaluate the organisers' practical experience.

To obtain the project organisers' standpoint, we prepared and performed research in the form of a questionnaire-based survey. The respondents were asked about their attitudes to PM as a tool for improving the effectiveness of EU projects, the application of a single PM methodology, the existence of a PMO within the organiser's organization, and familiarity with the basic PM methods applied in general practice, as well as their application within the implementation of EU projects. The PM methods chosen for assessment were those defined by Spolecnost pro projektove rizeni (SPR) on the basis of a wide-ranging professional discussion within research into them as basic PM methods. SPR has been representing IPMA in the Czech Republic since 1993, and is the guarantor of IPMA certifications. 
The respondents were also asked identification questions. They were asked to identify their organization, the project, the respective sector of their organization, the respondent's position within the project, and the operational programme through which the project was financed.

The choice of respondents was made in relation to projects. It was based on the project database published by the Ministry of Regional Development, Czech Republic as of 6 February 2013, listing 40,908 approved projects (the Ministry of Regional Development CZ, 2013). Using the random number generator in Microsoft Office Excel, each project was assigned a number. By putting the data in number order, we obtained a sequence from which the first 500 projects were chosen $(1.2 \%$ of the total number of projects). Contact data for these projects were found in the databases of the respective operational programmes, or directly on the internet pages of the projects.

Representatives of the chosen projects were addressed by email in two rounds. The questionnaire was published on the internet using the Lime Survey application from the 10th April 2013 to 30th April 2013. 158 respondents answered the questions. The rate of return was $31.60 \%$.

With respect to the identification of respondents and projects, a total number of 152 respondents identified 88 projects $(57.90 \%)$ from the public sector, 27 projects $(17.76 \%)$ from the nonprofit sector, and 37 projects (24.34 $\%)$ from the private sector. The survey involved 106 project managers or coordinators $(80.92 \%$ of the respondents), 13 finance managers (9.92\% of the respondents), and 12 persons whose positions within the project were of another character $(9.16 \%$ of the respondents).

To compare the level of familiarity with and application of PM methods within EU projects with the levels found in general practice, the research team used the outputs of the survey conducted by SPR in the Czech Republic in April and May 2012 (Kratky et al., 2012), where the first author of this paper was participating as a member of SPR. Within this survey, we obtained answers from 178 respondents representing a wide range of branches and organizations. Most of them were project managers, portfolio managers, programme managers, and project team members.

The obtained data were subsequently processed using IBM SPSS Statistics software. The data were analyzed using the tools of exploration and inferential analysis. The validity of the hypotheses enumerated above was verified at a significance level of $5 \%$.

\section{Project Management and EU Projects}

The respondents evaluated the application of a single PM methodology and the existence of a PMO in the project organiser's organization. They also specified their stand on $\mathrm{PM}$ as a possible tool for improving the effectiveness of EU projects. In addition, the respondents expressed their opinions on basic PM methods, i.e. how much they were familiar with them and to what extent they made use of them within the implementation of EU projects. These outcomes were subsequently compared with the outputs of the survey performed by SPR (Kratky et al., 2012).

\section{Project Management as a Tool Improving the Effectiveness of EU Projects}

The respondents were asked whether, in their opinion, the application of PM leads to the improved effectiveness of EU projects. The respondents' answers to this question were definitely positive; 116 out of the total number of 158 respondents, i.e. $73.4 \%$, stated that PM can improve the effectiveness of these projects.

\section{Single Project Management Methodology in the Organiser's Organization}

In the case of the implementation of more than one project in an organization, a single PM methodology is essential as it can also help to improve the effectiveness of project implementation. The respondents were asked whether they applied a single PM methodology defined on the level of an organization. For comparison, it is possible to use the outcomes of the survey conducted by SPR (Kratky et al., 2012). For the outcomes of the survey and the comparison, see Table 1. The term "General Practice" covers the outputs of the research conducted by SPR.

Table 1

Single Methodology by Project Type Crosstab

\begin{tabular}{|c|c|c|c|c|}
\hline & \multicolumn{2}{|c|}{ Single methodology } & \multirow{2}{*}{ Total } \\
\hline & & No & Yes & \\
\hline \multirow{3}{*}{ Count } & General practice & 103 & 75 & 178 \\
\hline & EU projects & 63 & 95 & 158 \\
\hline & Total & 166 & 170 & 336 \\
\hline
\end{tabular}

Pearson Chi-Square test: $\chi 2=10.839(d f=1), P=0.001$

Source: Own processing on the basis of the respondents' answers

$60.1 \%$ of respondents stated that they applied a single PM methodology defined on the level of their organization within the implementation of EU projects, whereas within general practice it was only $42.1 \%$ of respondents. Based on the Chi-Square test, the identified difference is statistically significant. The above implies that a single methodology is used in the management of EU projects more often than in project implementation in general. This fact is apparently related to the extensive system of rules connected with EU projects.

The frequency of applying a single PM methodology in EU projects was also analyzed according to whether the respondents considered $\mathrm{PM}$ as a tool leading to the improved effectiveness of these projects; see the crosstab in Table 2.

Table 2

Effectiveness as Affected by the Existence of Single Methodology

\begin{tabular}{|c|c|c|c|c|c|}
\hline & \multicolumn{2}{|c|}{ Effectiveness } & \multirow{2}{*}{ Total } \\
\hline & & & No & Yes & \\
\hline \multirow{3}{*}{ Count } & \multirow{2}{*}{$\begin{array}{l}\text { Single } \\
\text { methodology }\end{array}$} & No & 20 & 43 & 63 \\
\hline & & Yes & 22 & 73 & 95 \\
\hline & \multicolumn{2}{|l|}{ Total } & 42 & 116 & 158 \\
\hline
\end{tabular}

Pearson Chi-Square test: $\chi 2=1.432(d f=1), P=0.232$

Source: Own processing on the basis of the respondents' answers

For the evaluation of Hypothesis H1 (EU project organisers who have introduced a single PM methodology are more likely to evaluate $\mathrm{PM}$ as a tool leading to the improved effectiveness of these projects), the Chi-Square 
test was used. The Chi-Square test did not reveal any relationship between the monitored features. Therefore, it is possible to reject Hypothesis H1. This probably relates to the fact that the use of a single methodology is largely connected with the rules set by the providers regardless of the organiser's approach, experience, or previous practice.

\section{Project Management Office in the Organiser's Organization}

Regarding the assessment of the existence of a PMO in the organiser's organization, the respondents were asked whether their organization engaging in an EU project had either a formally or informally anchored PMO. The outputs of the research conducted by SPR (Kratky et al., 2012) were used for comparison. For the research outcomes and the comparison, see Table 3. The term "General Practice" covers the outputs of the research conducted by SPR.

Table 3

PMO by Project Type Crosstab

\begin{tabular}{|c|l|c|c|c|}
\hline \multicolumn{2}{|c|}{} & \multicolumn{2}{|c|}{ PMO } & \multirow{2}{*}{ Total } \\
\cline { 3 - 4 } \multicolumn{2}{c|}{} & No & Yes & \\
\hline \multirow{3}{*}{ Count } & General practice & 102 & 76 & 178 \\
\cline { 2 - 4 } & EU projects & 69 & 89 & 158 \\
\cline { 2 - 4 } & Total & 171 & 165 & 336 \\
\hline
\end{tabular}

Pearson Chi-Square test: $\chi 2=6.224(d f=1), P=0.013$

Source: Own processing on the basis of the respondents' answers

The existence of a PMO in EU project organisers' organizations was confirmed by $56.3 \%$ of respondents, and $42.7 \%$ in the general practice. Based on the Chi-Square test, the identified difference is statistically significant. Therefore, it is possible to state that PMOs are represented in organizations engaging in EU projects more often than in the general practice.

However, compared to foreign practice, the number of PMOs is, according to the monitored surveys, lower in the Czech Republic. For instance, according to a worldwide survey conducted by PricewaterhouseCoopers in 2007, PMOs were present in $80 \%$ of organizations (PricewaterhouseCoopers, 2007); according to another worldwide survey conducted in 2011 they were present in $67 \%$ of organizations (Project Management Institute, 2012).

The frequency of PMOs was, similarly to the application of a single methodology, analyzed in relation to whether the respondents considered PM as a tool leading to the improved effectiveness of EU projects. The frequency analysis in Table 4 implies the statistical significance of this relation.

Table 4

Effectiveness as Affected by the Existence of PMO

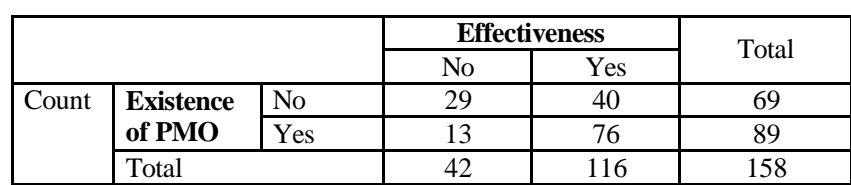

Pearson Chi-Square test: $\chi^{2}=14.976(d f=1), P=0.000$

Source: Own processing on the basis of the respondents' answers

Hypothesis H2 (EU project organisers who have introduced a PMO are more likely to evaluate PM as a tool leading to the improved effectiveness of these projects) was evaluated on the basis of the Chi-Square test. It is possible to state that the existence of a PMO is connected with the approach taken by EU projects organisers to PM; specifically, it shows positive experience with the concentration of project support activities into a PMO. Hypothesis H2 was confirmed.

\section{Familiarity with Project Management Methods among EU Project Organisers}

The respondents were given a list of the basic PM methods and asked which of these methods they knew. The column "EU projects" in Table 5 shows the level of awareness of the basic PM methods on the part of respondents from EU projects.

The outcomes are compared with the outputs of the survey conducted by SPR (Kratky et al., 2012), which evaluated the same methods from the point of view of general practice in the Czech Republic; see Table 5, column "General Practice".

Table 5

Familiarity with Basic PM Methods

\begin{tabular}{|l|c|c|c|c|c|}
\hline \multirow{2}{*}{$\begin{array}{l}\text { Project Management } \\
\text { Methods }\end{array}$} & \multicolumn{2}{|c|}{ Familiarity*) } & \multicolumn{3}{c|}{ Chi-Square Test } \\
\cline { 2 - 6 } & $\begin{array}{c}\text { EU } \\
\text { projects }\end{array}$ & $\begin{array}{c}\text { General } \\
\text { practice }\end{array}$ & $\chi 2$ & df & P-value \\
\hline Logical Framework & $81.5 \%$ & $93.2 \%$ & 7.768 & 1 & 0.005 \\
\hline $\begin{array}{l}\text { Pre-Project Study with } \\
\text { Formalized Structure }\end{array}$ & $91.7 \%$ & $92.5 \%$ & 0.057 & 1 & 0.812 \\
\hline $\begin{array}{l}\text { Financial Evaluation } \\
\text { of the Project (e.g. } \\
\text { IRR, NPV) }\end{array}$ & $82.8 \%$ & $96.7 \%$ & 13.623 & 1 & 0.000 \\
\hline WBS & $39.5 \%$ & $87.1 \%$ & 62.771 & 1 & 0.000 \\
\hline $\begin{array}{l}\text { Time Planning Using } \\
\text { Schedules and CPM }\end{array}$ & $72.0 \%$ & $97.6 \%$ & 32.324 & 1 & 0.000 \\
\hline Critical Chain Method & $56.7 \%$ & $89.4 \%$ & 33.682 & 1 & 0.000 \\
\hline EVM & $52.2 \%$ & $83.2 \%$ & 27.746 & 1 & 0.000 \\
\hline $\begin{array}{l}\text { Formalized Risk } \\
\text { Analysis }\end{array}$ & $77.7 \%$ & $95.8 \%$ & 17.878 & 1 & 0.000 \\
\hline $\begin{array}{l}\text { Formalized Project } \\
\text { Communication Plan }\end{array}$ & $72.6 \%$ & $93.2 \%$ & 18.691 & 1 & 0.000 \\
\hline $\begin{array}{l}\text { Responsibility } \\
\text { Assignment Matrix or } \\
\text { Linear Responsibility } \\
\text { Chart }\end{array}$ & $68.0 \%$ & $93.3 \%$ & 25.743 & 1 & 0.000 \\
\hline Agile Methods & $40.8 \%$ & $56.6 \%$ & 6.371 & 1 & 0.012 \\
\hline
\end{tabular}

*) Frequency representation of the respondents stating that they knew the given method.

Source: Own processing on the basis of the respondents' answers and the survey conducted by SPR (Kratky et al., 2012)

Except for the Pre-Project Study with Formalized Structure, where it was not possible to demonstrate any difference, the level of knowledge of project management methods in all other identified areas was higher in general practice than in EU projects. The Pre-Project Study with Formalized Structure is, within the rules of the system of EU project funding, an obligatory part of the application for support of a project in some operational programmes, while in other operational programmes it is a recommended tool for specifying the project intention. Therefore, the awareness of this method in the context of EU support is comparable to general practice. 
Hypothesis H3 (EU project organisers’ familiarity with PM methods is on a lower level than it is with project organisers in general) was evaluated on the basis of the above comparison. Familiarity with the basic PM methods among EU project organisers was on a relatively high level. However, it still did not reach the level of general practice (familiarity was significantly lower in 10 out of the 11 monitored methods; in 1 method it was comparable). Hypothesis H3 was confirmed.

\section{Application of Project Management Methods by EU Project Organisers}

Next, the respondents were asked to identify from the list of basic PM methods those which they used within EU projects. The column "EU projects" in Table 6 shows the rate of application of the basic PM methods by EU project organisers. For comparison, the column "General Practice" shows the rate of application of the above methods in general practice, as it was identified by the survey conducted by SPR (Kratky et al., 2012).

Table 6

Application of Basic PM Methods

\begin{tabular}{|l|c|c|c|c|c|}
\hline \multirow{2}{*}{$\begin{array}{l}\text { Project Management } \\
\text { Methods }\end{array}$} & \multicolumn{2}{|c|}{ Application*) } & \multicolumn{3}{|c|}{ Chi-Square Test } \\
\cline { 2 - 6 } projects & $\begin{array}{c}\text { General } \\
\text { practice }\end{array}$ & $\chi^{2}$ & df & P-value \\
\hline Logical Framework & $35.7 \%$ & $40.2 \%$ & 0.579 & 1 & 0.447 \\
\hline $\begin{array}{l}\text { Pre-Project Study with } \\
\text { Formalized Structure }\end{array}$ & $49.7 \%$ & $55.8 \%$ & 1.032 & 1 & 0.310 \\
\hline $\begin{array}{l}\text { Financial Evaluation } \\
\text { of the Project (e.g. } \\
\text { IRR, NPV) }\end{array}$ & $28.7 \%$ & $61.8 \%$ & 30.841 & 1 & 0.000 \\
\hline WBS & $6.4 \%$ & $66.4 \%$ & 110.645 & 1 & 0.000 \\
\hline $\begin{array}{l}\text { Time Planning Using } \\
\text { Schedules and CPM }\end{array}$ & $28.7 \%$ & $66.7 \%$ & 40.191 & 1 & 0.000 \\
\hline Critical Chain Method & $7.0 \%$ & $16.8 \%$ & 6.400 & 1 & 0.011 \\
\hline EVM & $10.8 \%$ & $16.8 \%$ & 2.038 & 1 & 0.153 \\
\hline $\begin{array}{l}\text { Formalized Risk } \\
\text { Analysis }\end{array}$ & $40.8 \%$ & $61.3 \%$ & 11.469 & 1 & 0.001 \\
\hline $\begin{array}{l}\text { Formalized Project } \\
\text { Communication Plan }\end{array}$ & $29.3 \%$ & $47.9 \%$ & 9.887 & 1 & 0.002 \\
\hline $\begin{array}{l}\text { Responsibility } \\
\text { Assignment Matrix or } \\
\text { Linear Responsibility } \\
\text { Chart }\end{array}$ & $26.8 \%$ & $61.3 \%$ & 33.328 & 1 & 0.000 \\
\hline Agile Methods & $3.8 \%$ & $19.8 \%$ & 17.562 & 1 & 0.000 \\
\hline
\end{tabular}

*) Frequency representation of the respondents who stated that they used the given method.

Source: Own processing on the basis of the respondents' answers and the survey conducted by SPR (Kratky et al., 2012)

In the case of EU projects, the frequency of application of obligatory or recommended methods (Pre-Project Study with Formalized Structure, Formalized Risk Analysis, Logical Framework) is the highest. Thus, in these cases, the frequency of application in EU projects is similar to the frequency of application in general practice.

Hypothesis H4 (EU project organisers make use of PM methods to a smaller extent than project organisers in general) was evaluated on the basis of the above comparison. It is not possible to demonstrate any difference in the application of the Logical Framework, the Pre-Project Study with Formalized Structure, and the EVM. The other methods are probably used less in the implementation of EU projects than in general practice. It is possible to conclude that within EU projects most PM methods are used significantly less than in general practice (in 8 out of the 11 monitored methods, application is significantly lower; in 3 methods it is comparable). Hypothesis H4 was confirmed.

\section{Familiarity with, and Application of Project Management Methods by EU Project Organisers in Relation to Their Attitudes to Project Management}

The above outputs, i.e. familiarity with, and application of the basic PM methods, can be further assessed in relation to the evaluation of PM as a tool improving the effectiveness of EU projects. It is possible to assume that in the case of a positive standpoint, the respondents will be more familiar with PM methods and will also use them to a larger extent.

Table 7 presents the outcomes of the frequency analysis of the familiarity with PM methods in relation to PM effectiveness. Hypothesis H5 (EU project organisers who evaluate PM as a tool for improving the effectiveness of these projects have broader familiarity with the basic PM methods) was evaluated on the basis of these outcomes

Table 7

\section{Familiarity with PM Methods in Relation to PM} Effectiveness

\begin{tabular}{|c|c|c|c|c|c|}
\hline \multirow{2}{*}{$\begin{array}{l}\text { Project Management } \\
\text { Methods }\end{array}$} & \multicolumn{2}{|c|}{ Familiarity *) } & \multicolumn{3}{|c|}{ Chi-Square Test } \\
\hline & Effective & $\begin{array}{c}\text { Non- } \\
\text { effective }\end{array}$ & $\chi^{2}$ & df & $\begin{array}{c}\mathrm{P}- \\
\text { value }\end{array}$ \\
\hline Logical Framework & $82.6 \%$ & $78.6 \%$ & 0.333 & 1 & 0.564 \\
\hline $\begin{array}{l}\text { Pre-Project Study with } \\
\text { Formalized Structure }\end{array}$ & $93.9 \%$ & $85.7 \%$ & 2.723 & 1 & 0.099 \\
\hline $\begin{array}{l}\text { Financial Evaluation of } \\
\text { the Project (e.g. IRR, } \\
\text { NPV) }\end{array}$ & $83.5 \%$ & $81.0 \%$ & 0.138 & 1 & 0.710 \\
\hline WBS & $43.5 \%$ & $28.6 \%$ & 2.861 & 1 & 0.091 \\
\hline $\begin{array}{l}\text { Time Planning Using } \\
\text { Schedules and CPM }\end{array}$ & $75.7 \%$ & $61.9 \%$ & 2.882 & 1 & 0.090 \\
\hline Critical Chain Method & $59.1 \%$ & $50.0 \%$ & 1.045 & 1 & 0.307 \\
\hline EVM & $54.8 \%$ & $45.2 \%$ & 1.123 & 1 & 0.289 \\
\hline $\begin{array}{l}\text { Formalized Risk } \\
\text { Analysis }\end{array}$ & $83.5 \%$ & $61.9 \%$ & 8.265 & 1 & 0.004 \\
\hline $\begin{array}{l}\text { Formalized Project } \\
\text { Communication Plan }\end{array}$ & $78.3 \%$ & $57.1 \%$ & 6.899 & 1 & 0.009 \\
\hline $\begin{array}{l}\text { Responsibility } \\
\text { Assignment Matrix or } \\
\text { Linear Responsibility } \\
\text { Chart }\end{array}$ & $74.8 \%$ & $50.0 \%$ & 8.705 & 1 & 0.003 \\
\hline Agile Methods & $44.3 \%$ & $31.0 \%$ & 2.286 & 1 & 0.131 \\
\hline
\end{tabular}

*) Frequency of respondents who knew the given method within the group "Effective" (who considered PM as a tool improving the effectiveness of EU projects) and within the group "Non-effective" (who did not consider PM as a tool improving the effectiveness of EU projects).

Source: Own processing on the basis of the respondents' answers

The frequency analysis (see more in Table 7) implies that the respondents evaluating $\mathrm{PM}$ as a tool increasing the effectiveness of EU projects were slightly more familiar with the basic PM methods. However, the identified difference is, with the exception of three methods (Formalized Risk Analysis, Formalized Project Communication Plan, and Responsibility Assignment Matrix or Linear Responsibility Chart), statistically insignificant. Nevertheless, in view of the achieved outcomes, it is possible to consider Hypothesis H5 as proven.

Table 8 presents the outcomes of the frequency analysis of the application of PM methods in relation to PM effectiveness. 
Hypothesis H6 (EU project organisers who evaluate PM as a tool for improving the effectiveness of these projects are more likely to apply the basic PM methods) was evaluated on the basis of these outcomes.

Table 8

Application of PM Methods in Relation to PM Effectiveness

\begin{tabular}{|l|c|c|c|c|c|}
\hline \multirow{2}{*}{$\begin{array}{l}\text { Project Management } \\
\text { Methods }\end{array}$} & \multicolumn{3}{|c|}{ Application * } & \multicolumn{3}{|c|}{ Chi-Square Test } \\
\cline { 2 - 6 } & Effective & $\begin{array}{c}\text { Non- } \\
\text { effective }\end{array}$ & $\chi^{2}$ & df & $\begin{array}{c}\text { P- } \\
\text { value }\end{array}$ \\
\hline Logical Framework & $42.6 \%$ & $16.7 \%$ & 9.023 & 1 & 0.003 \\
\hline $\begin{array}{l}\text { Pre-Project Study with } \\
\text { Formalized Structure }\end{array}$ & $57.4 \%$ & $28.6 \%$ & 10.221 & 1 & 0.001 \\
\hline $\begin{array}{l}\text { Financial Evaluation of } \\
\text { the Project (e.g. IRR, } \\
\text { NPV) }\end{array}$ & $32.2 \%$ & $19.0 \%$ & 2.592 & 1 & 0.107 \\
\hline WBS & $7.8 \%$ & $2.4 \%$ & 1.529 & 1 & 0.216 \\
\hline $\begin{array}{l}\text { Time Planning Using } \\
\text { Schedules and CPM }\end{array}$ & $32.2 \%$ & $19.0 \%$ & 2.592 & 1 & 0.107 \\
\hline Critical Chain Method & $6.1 \%$ & $9.5 \%$ & 0.558 & 1 & 0.455 \\
\hline EVM & $13.9 \%$ & $2.4 \%$ & 4.237 & 1 & 0.040 \\
\hline $\begin{array}{l}\text { Formalized Risk } \\
\text { Analysis }\end{array}$ & $48.7 \%$ & $19.0 \%$ & 11.199 & 1 & 0.001 \\
\hline $\begin{array}{l}\text { Formalized Project } \\
\text { Communication Plan }\end{array}$ & $35.7 \%$ & $11.9 \%$ & 8.375 & 1 & 0.004 \\
\hline $\begin{array}{l}\text { Responsibility } \\
\text { Assignment Matrix or } \\
\text { Linear Responsibility } \\
\text { Chart }\end{array}$ & $31.3 \%$ & $14.3 \%$ & 4.547 & 1 & 0.033 \\
\hline Agile Methods & $4.3 \%$ & $2.4 \%$ & 0.324 & 1 & 0.569 \\
\hline
\end{tabular}

*) Frequency of respondents who used the given method within the group "Effective" (who considered PM as a tool improving the effectiveness of EU projects) and within the group "Non-effective" (who did not consider PM as a tool improving the effectiveness of EU projects).

Source: Own processing on the basis of the respondents' answers

The frequency analysis (see more in Table 8) implies that among the respondents evaluating PM as a tool increasing the effectiveness of EU projects, the application of the basic PM methods was at a significantly higher level. It was not possible to demonstrate a statistically significant difference in the methods of Financial Evaluation of the Project, WBS, Time Planning Using Schedules and CPM, Critical Chain Method and Agile Methods. Nevertheless, in view of the achieved outcomes, it is possible to consider Hypothesis $\mathrm{H} 6$ as proven.

Table 9 presents the Kappa values, which make it possible to measure the degree of dependence between the application of PM methods by the respondents and the effectiveness of PM in EU projects as perceived by them.

Table 9

The Degree of Dependence between the Application of PM Methods by Respondents and the Effectiveness of PM in EU Projects as Perceived by Them

\begin{tabular}{|l|c|}
\hline Project Management Methods & Kappa \\
\hline Logical Framework & 0,179 \\
\hline Pre-Project Study with Formalized Structure & 0,225 \\
\hline Financial Evaluation of the Project (e.g. IRR, NPV) & Not significant \\
\hline WBS & Not significant \\
\hline Time Planning Using Schedules and CPM & Not significant \\
\hline Critical Chain Method & Not significant \\
\hline EVM & 0,066 \\
\hline Formalized Risk Analysis & 0,214 \\
\hline Formalized Project Communication Plan & 0,156 \\
\hline $\begin{array}{l}\text { Responsibility Assignment Matrix or Linear } \\
\text { Responsibility Chart }\end{array}$ & 0,110 \\
\hline Agile Methods & Not significant \\
\hline
\end{tabular}

Source: Own processing on the basis of the respondents' answers

Table 9 shows that a higher degree of dependence was identified particularly in methods that are applicable across more PM knowledge areas and within most project life cycle stages.

\section{Evaluation and Proposed Measures}

The application of PM methods is, from the point of view of EU project organisers, one of the ways that could improve the effectiveness of EU projects (Spalek, 2014). However, existing rules governing the preparation of applications and the implementation of EU projects do not lead to the application of PM methods to a desirable extent, as, in comparison with general practice, familiarity with them is on a significantly lower level, and they are also applied less often.

On the basis of the literature review, the analysis of methodologies and rules set by the providers of EU funds in the Czech Republic, and the respondents' answers, it is possible to propose measures that could bring desirable changes in EU project implementation rules from the point of view of the application of PM methods in the subsequent PP. These measures might include:

- precise definition of the project objective using PreProject Study with Formalized Structure, Financial Evaluation of the Project, and Logical Framework;

- definition of outputs and activities within the project using WBS and Time Planning Using Schedules and CPM;

- definition of the project budget and cash flows on the basis of WBS and of the time schedule of activities, with a higher degree of flexibility with respect to the incorporation of potential change requirements within project implementation;

- increased application of Formalized Risk Analysis within project implementation;

- monitoring of project outputs, not only on the basis of quantitative evaluation, but mainly on the basis of the qualitative evaluation of project outputs;

- assessment of projects from the point of view of their effectiveness, economy, and purposefulness using Financial Evaluation of the Project - specifically when approving and making a final evaluation;

- the application of methods suitable for project planning and implementation (EVM, Formalized Project Communication Plan, Responsibility Assignment Matrix, etc.) within the recommended procedures for processing applications and project implementation;

- the utilisation of available PM standards (PMI, IPMA, PRINCE 2);

- a general increase in the pressure to observe the project triple imperative.

Implementation of the above recommendations should lead to improvements in the effectiveness of the system of providing EU funds in the subsequent PP. At the same time, it should result in an increase in familiarity with, and the application of PM methods in general practice. 


\section{Conclusions}

The conducted survey focused on EU projects in the PP 2007-2013 shows that PM methods were not applied to a sufficient extent within project planning and implementation, particularly in view of the level of their application in general practice. The degree of application of the Pre-Project Study with Formalized Structure shows that obligations or recommendations to apply PM methods based on the provider's methodical instructions would significantly increase familiarity with these methods in practice and the rate of their application. As a result, this measure could be one of the ways to improve the effectiveness of the implementation of these projects. PM methods that are compulsory or recommended within EU project methodologies in the subsequent PP should mainly include methods applicable within more PM knowledge areas and within more project life cycle stages (Logical Framework, Pre-Project Study with Formalized Structure, Formalized Risk Analysis and Formalized Project Communication Plan), as they have more significant impacts on the perceived effectiveness of PM as a tool improving the effectiveness and efficiency of EU projects.

The data collection was conducted in the middle of PP 2007-2013 to acquire recommendations for the subsequent PP 2014-2020. This can be considered as a certain limitation of this study, as a number of the projects had not been completed at that time. At the end of PP 2007-2013 (covering EU projects implemented until the end of 2015), it would be useful to perform similar research with respect to finished EU projects. It would be interesting to extend the research by analysing the dependence between the application of PM methods and the success of implemented projects, and also by analysing the familiarity with, and the application of PM methods with respect to individual operational programmes, types of projects, or sectors of the organisers’ activity.

Consequently, during PP 2014-2020, it would be useful to compare both PPs and evaluate whether there have been any positive changes.

\section{References}

Acebes, F., Pajares, J., Galan, J. M., \& Paredes, A. L. (2012). Beyond Earned Value Management: A Graphical Framework for Integrated Cost, Schedule and Risk Monitoring. Procedia - Social and Behavioral Sciences, 74, 181189. https://doi.org/10.1016/j.sbspro.2013.03.027

Association of Project Management. (2006). APM Body of Knowledge. Rochester: Association of Project Management.

Beck, K. et al. (2001). Manifesto for Agile Software Development. Available from internet: http://www.agilemanifesto.org/

Benta, D., Podean, I. M., \& Mircean, C. (2011). On Best Practices for Risk Management in Complex Projects. Informatica Economica, 15 (2), 142-152.

Cambell, H., \& Brown, R. (2003). Benefit-Cost Analysis. Cambridge: Cambridge University Press.

de Carvalho, M. M., Patah, L. A. \& Bido, D. D. (2015). Project Management and its Effects on Project Success: Crosscountry and Cross- industry Comparisions. International Journal of Project Management, 33(7), $1509-1522$. https://doi.org/10.1016/j.ijproman.2015.04.004

Dettmer, H. M. (1997). Goldratt's Theory of Constraints: A System Approach to Continuous Improvement. Milwaukee: ASQ Quality Press.

Dow, W., \& Taylor, B. (2010). Project Management Communications Bible. Indianapolis: John Wiley \& Sons.

Ernst \& Young. (2013). Research into Project Management in the CZ and Slovakia. (in Czech) Available from internet: http://www.ey.com/Publication/vwLUAssets/Pr\%C5\%AFzkum_\%C5\%99\%C3\%ADzen\%C3\%AD_2013/\$FILE/EY _Pruzkum\%20rizeni\%20projektu\%20v\%20CR\%20a\%20SR\%202013.pdf.

Ernst \& Young. (2012). Project Management in the CZ 2012. (in Czech) Available from internet: http://www.ey.com/Publication/vwLUAssets/PMP_Survey_2012/\$FILE/EY_Pruzkum\%20rizeni\%20projektu\%20v \%20CR\%20a\%20SR\%202012.pdf.

Gareis, R. (2005). Happy Projects! Vienna: Manz.

Gerbault, J. (2012). Round Table, Adding Value to EU-funded Projects. Languages, Cultures and Virtual Communities, 34, 5-8. http://dx.doi.org/10.1016/j.sbspro.2012.02.002

Goldratt, E. M. (1997). Critical Chain. New York: The North River Press.

Grant, K., \& Pennypacker, J. S. (2006). Project Management Maturity: An Assessment of Project Management Capabilities among and between Selected Industries. IEEE Transactions on Engineering Management, 53(1), 59-68. https://doi.org/10.1109/TEM.2005.861802 
Hapanova, T., \& Al-Jibri, S. (2009). Identifying Key Performance Indicators for Use in Control of Pre-project Stage Process in Construction. International Journal of Productivity and Performance Management, 58(2), $160-173$. https://doi.org/10.1108/17410400910928743

Hillier, F. S., \& Lieberman, G. J. (2005). Introduction to Operations Research. New York: McGraw-Hill.

Hofman, M. (2014). Models of PMO Functioning in a Multi-project Environment. Procedia - Social and Behavioral Sciences, 119, 46-54. http://dx.doi.org/10.1016/j.sbspro.2014.03.008

Hrazdilova Bockova, K. (2009). Future Scenarios of Czech Project Management. E+M Economics and Management, 12(3), 6-18, (in Czech).

International Organization for Standardization. (2012). ISO 21500 Guidance on Project Management. Available from internet: http://www.iso.org/iso/home/news_index/news_archive/news.htm?refid=Ref1662.

Joslin, R., \& Muller, R. (2015). Relationship between a Project Management Methodology and Project Success in Different Project Governance Contexts. International Journal of Project Management, 33(6), 1377-1392. http://dx.doi.org/10.1016/j.ijproman.2015.03.005

Kerzner, H. R. (2005). Using the Project Management Maturity Model: Strategic Planning for Project Management. Hoboken: John Wiley \& Sons.

Koerner, M. (2005). Declaration of Interdependence. Available from internet: http://pmdoi.org/.

Kostalova, J., Tetrevova, L., \& Patak, M. (2015). The System of Support for Projects Co-financed by EU Funds in the Czech Republic. Transylvanian Review of Administrative Sciences, 45E/June, 97-115. https://doi.org/10.1016/j.sbspro.2014.09.087

Kratky, J., \& Tetrevova, L. (2012). Social Return on Investment Analysis in the Context of Corporate Social Responsibility. In: Zlin, Czech Rebublic: the 1st WSEAS International Conference on Economics, Political and Law Science, 20-22 September, 2012.

Kratky, J. et al. (2012). The Report on Project Management in the CZ, The Report on the Research Outcomes. Brno: Spolecnost pro projektove rizeni (in Czech).

Krisciunaite-Kaciuskiene, I. (2013). Programming of the EU Structural Assistance for 2014-2020: a Search for Effectiveness. Inzinerine Ekonomika-Engineering Economics, 24(5), 447-455. http://dx.doi.org/10.5755/j01.ee. 24.5.5355

Lappe, M., \& Spang, K. (2014). Investment in Project Management Are Profitable: A Case Study-based Analysis of the Relationship between the Costs and Benefits of Project Management. International Journal of Project Management, 32(4), 603-612.http://dx.doi.org/10.1016/j.ijproman.2013.10.005

Mariusz, H. (2014). Models of PMO Functioning in a Multi-project Environment. Procedia - Social and Behavioral Sciencies, 119, 46-54. http://dx.doi.org/10.1016/j.sbspro.2014.03.00

Melnic, A., \& Puiu, T. (2011). The Management of Human Resources within Projects: the Structures of the Project Team, the Responsibility. Economy Transdisciplinary Cognition, 14(1), 476-484.

Mihaila, A., Benta, D., \& Rusu, L. (2014). Framework for Automated Reporting in EU Funded Projects. International Journal of Computers Communications \& Control, 9(6), 721-729. https://doi.org/10.15837/ijccc.2014.6.1477

Milosevic, D., \& Patanakul, P. (2005). Standardized Project Management May Increase Development Projects Success. International Journal of Project Management, 23(3), 181-192. http://dx.doi.org/10.1016/j.ijproman.2004.11.002

Ministry of Regional Development CZ. (2016). The Quarterly Monitoring Report on the Course of Drawing from Structural Funds, Cohesion Fund in the Programming Period 2007-2013, Quarter 4. (in Czech). Available from internet: http://www.strukturalni-fondy.cz/getmedia/53d0a01b-dbbc-4904-9998-07a368124b1e/Ctvrtletni-zprava-oimplementaci-DoP-2014-2020.pdf.

Ministry of Regional Development CZ. (2013). The Current Monthly Monitoring Report: January. (in Czech), Available from internet: http://www.harianregional.com/2016/01/penurunan-harga-bbm-terbaru-sudah.html.

Muller, R., Gluckler, J., \& Aubry, M. (2013). A Relational Typology of Project Management Offices. Project Management Journal, 44(1), 59-76. http://dx.doi.org/10.1002/pmj.21321

Norman, E. S., Brotherton, S. A., \& Fried, R. T. (2008). Work Breakdown Structures: The Foundation for Project Management Excellence. Hoboken: John Wiley \& Sons. https://doi.org/10.1002/9780470432723

Norwegian Agency for Development Cooperation. (1999). The Logical Framework Approach. Oslo: NORAD. 
Patanakul, P., Iewwongcharoen, B., \& Milosevic, D. (2010). An Empirical Study on the Use of Project Management Tools and Techniques across Project Life-Cycle and their Impact on Project Success. Journal of General Management, 35(3), 41-65.https://doi.org/10.1177/030630701003500304

Pitas, J. et al. (2010). National Standard Competences of Project Management Version 3.1. Brno: VUT.

Pricewaterhousecoopers. (2007). Insights and Trends: Current Programme and Project Management Practices. Available from internet: http://www.pwc.com/us/en/operations-management/assets/pwc-global-project-management-surveysecond-survey-2007.pdf

Projec Management Institute. (2012). Pulse of the Profession. Available from internet: http://www.pmi.org/ /media/PDF/Research/2012_Pulse_of_the_profession.ashx

Project Management Institute. (2005). Practice Standard for Earned Value Management. Newton Square: Project Management Institute.

Projec Management Institute. (2004). A Guide to the Project Management Body of Knowledge. Newton Square: Project Management Institute.

Rodney, E., Ducq, Y., Breysse, D., \& Ledoux, Y. (2015). An Integrated Management Approach of the Project and Project Risks. IFAC-PapersOnline, 48(3), 535-540. http://dx.doi.org/10.1016/j.ifacol.2015.06.136

Spalek, S. (2014). Finding a New Way to Increase Project Management Effectiveness in Terms of Time Reduction. Inzinerine Ekonomika-Engineering Economics, 25(5), 538-548. http://dx.doi.org/10.5755/j01.ee.25.5.8419 Spalek, S. (2013). Improving Industrial Engineering Performance through a Successful Project Management Office. Inzinerine Ekonomika-Engineering Economics, 24(2), 88-98. http://dx.doi.org/10.5755/j01.ee.24.2.3087

Spundak, M. (2014). Mixed Agile/Traditional Project Management Methodology - Reality or Illusion? Procedia - Social and Behavioral Sciences, 119, 939-948. http://dx.doi.org/10.1016/j.sbspro.2014.03.10

Storms, K. (2008). Earned Value Management Implementation in an Agency Capital Improvement Program. Cost Engineering, 50(12), 17-40.

Tetrevova, L. (2006). Project Finance. Prague: Professional Publishing, (in Czech).

Yang, T., \& Chiu-Wen, Ch. (2009). An Incentive Pay System for Project Management Based on Responsibility Assignment Matrix and Fuzzy Linguistic Variables. Expert System with Applications, 36(10), 12585-12591. https://doi.org/10.1016/j.eswa.2009.05.067

Zizlavsky, O. (2014). Net Present Value Approach: Method for Economic Assessment of Innovation Projects. Procedia Social and Behavioral Sciences, 156, 506-512. http://dx.doi.org/10.1016/j.sbspro.2014.11.230

The article has been reviewed.

Received in November, 2015; accepted in June, 2017. 